\title{
Study and Design of the Laws and Regulations in the Achaemenids Empire
}

\author{
Seyed Ahmad Hosseini ${ }^{1}$, Mohammad Mahdi Darvishiniya ${ }^{2} \&$ Saba Sadat Hosseini ${ }^{3}$ \\ ${ }^{1}$ Management Department, Shahed University, Tehran, Iran \\ ${ }^{2}$ Shahed University, Tehran, Iran \\ ${ }^{3}$ Islamic Azad University, Qom, Iran \\ Correspondence: Mohammad Mahdi Darvishiniya, Shahed University, Tehran, Iran. E-mail: \\ M.Darvishiniya@alumni.ut.ac.ir
}

Received: December 23, 2015 Accepted: January 15, 2016 Online Published: March 31, 2016

doi:10.5539/jpl.v9n2p32 URL: http://dx.doi.org/10.5539/jpl.v9n2p32

\begin{abstract}
Given the importance of the law, which is essential, to manage government, this article aims to investigate and develop a system for the legislation and regulations in Iranian manner, to review and explain the features of Achaemenid Empire's laws and regulations. In collecting this research information, the tool "note" and note taking and data coding are used based on statistical population and according to the qualitative resulted data from the study of documents from qualitative content analysis (of directional). The data that were collected from September 1392 to December 1393 were related to 559 years BC To 330 BC. The study Result showed that the system of laws and regulations in that course includes "Collection and analysis of laws, Codified the draft laws, Legitimacy and the formalization of the laws, Records and information". In the end, a model based on the input, process and output is developed and presented.
\end{abstract}

Keywords: Achaemenid Empire, investigate and formulation of laws, the laws and regulation system, Traditions, imperial codified set of rules

\section{Introduction}

Humans cannot live separately from each other and to live with their fellows, they require rules that govern these relations and from here, the necessity of the current law between them can be felt. Rules that should regulate the relationships are called the law. Almost from the beginning of human creation, laws have been dominated in human societies, but with more advanced life, these rules have become more complex, so that today, people need to learn certain rules and regulations for most of the life matters. Documents and sources suggest that the laws and regulations of the Achaemenid Empire ware so advanced that have not been seen up to that time in history. Achaemenid has collected and have reviewed good laws of other affiliated nations and by using Persian laws and honorable traditions, have designed comprehensive and systematic set of rules that were proportional to that time; In addition, there are examples of documented rules for each Satrab. Such advanced laws and rules designing system, have provoked surprises in the researchers and amazed them.

\section{The Purposes of the Study}

The main objective of this study is to "review and explain the features of Achaemenid Empire laws and regulations" that its secondary objective is as follows:

1) Identify the components and the processes of the laws and regulation system in the Achaemenid Empire;

2) Determine the characteristics of the components and the processes of the laws and regulation system in the Achaemenid Empire.

\section{The Main Research Questions}

1) What are the components and process in the laws and regulation system of the Achaemenid Empire?

2) What features should each of the components and process of the laws and regulation system have in the Achaemenid Empire? 


\section{Research Theoretical Foundations}

In vocabulary, the law has below meanings: custom, order, scale, question, and manner and $\ldots$ and in a phrase, law is a general rule that is coincident on people and all those people's verdict was known from that rule (the Georgians, 1989: 199). Regardless of the differences in the expression, the law may be defined as follows "a legislative law is a written rule that is set by the qualified authority to regulate the behavior of people in the community and its violation deserves imposed sanctions by the government." According to the definition, the law has three characteristics: (1) implementation in a special government territory with with sovereignty and distinct identity; 2. it has a specific time territory, as it is eligible a specific location territory; 3 . It is binding and its implementation is guaranteed by the government (Beyg zadeh, 2009: 22).

The rule term is used in two senses: 1. credit, postural and contractual; that its provision is a sentence that expressly or necessarily implies an order or a prohibition. 2. Actual and genetic: that is a story of a noumen relationship that has not dealt with the validity, postual and contract (Mesbah, 1994: 114). The law has been divided in various ways, including the general and specific law, inconclusive and explainer and so on. However, the purpose of this classification is expressing the hierarchy that is existed in terms of validity and power between written law principles. According to this validation, the rules can be divided into three major groups: 1 . Constitution law: the rules that are based on the government and qualification of the country authorities and individual rights and liberties are constitutional law and it is superior to the other law. 2. Common law: the legislatures impose to the majority of the votes and after the head of the government, the executive branch and judiciary signatures, they bring it into force; 3. the executive branch orders and regulations that they are called approval letter, the regulations and the circulars in our office customs (Katouzian, 2008: 121-123). Legislation has three different stages that, after going through these stages the legal rule comes:1- Legislation: According to the article 58 of constitutional law,the legislation except in direct referring cases to public votes, the legislative power is applied through Shura Council.

Guardian Council will approve the legislation law and its role is to give validity to the available matter; furthermore, the Guardian Council has not the right to intervene in legislative policy and can only monitor the compliance approved by the parliament with the constitution law and start.2. Law Signature: Law arises after the Islamic Consultative parliament, the president's signature will turn it to an applicable rule, and executive and judicial officers and citizens are obliged to follow it. Another meaning of law signature is that the head of the government announces that the law was legislated in accordance with the basic principles and from now on, everybody obliged to follow it.according to article 125 of constitutional law, the president is obliged to sign the law and can prohibit from signing incomplete legislations.3. Publishing the law: when law enforcement had to be expected that its provisions would be published and publicized.

The civil law, at the end of the first modified article provides that:« The official newspaper is required to publish the legislation within 72 hours». A publication of the law is necessary for its implementation and in this way; deadline for implementation of the law begins. The government has not the authority to inform law to the public on any circumstances that it rather. However, everyone should know in advance that where the rules would be included so with continuing referring to it, they will be informed of their rights and obligations. Article 3 of the Civil law says: « Laws releasing should be made in the Official newspaper» (Katouzian, 2008: 131-135). The constitution of the Islamic Republic law had six steps, which included 1. Provide a constitutional law draft to the public; 2 . The Assembly of experts' constitutional law parliament; 3. Discussion and reviewing the constitutional law draft in groups of seven and commissions of thirteen of of Experts constitutional law parliament within 68 sessions; 4 . The final four-day maturity of experts' parliament; 5 . Final approval of constitutional law text by the Experts parliament on 11.15.1979; 6. The referendum of Islamic republic constitutional law on 11 and 12 December 1979 and the final approval by the nation (Khalili, 1993:86)

\section{A Review of Conducted Studies}

Many domestic and foreign researches about the Achaemenid have been conducted, including articles, books, researches, and... from domestic and foreign authors that are as the original translation of texts and tablets, observations and... Some of them are mentioned in Table 1. 
Table 1. Examples of conducted domestic and foreign researches on the subject of the Achaemenids (the researcher)

\begin{tabular}{ccc}
\hline & \multicolumn{2}{c}{ Domestic researches } \\
\hline The researcher & Year & Book/Article and... \\
\hline Hassan Pirniya & 2002 & Ancient Iran or detailed history of old Iran \\
Abbass Ghadyani & 2005 & History, culture and civilization of the Achaemenid period \\
Ali Sami & 2009 & Achaemenid Civilization \\
Parviz Rajabi & 2002 & Missing Millennium \\
Abdolazim Rezaei & 2002 & Ten thousand years history of Iran \\
\hline & & Foreign researches \\
\hline Ali Farazmand & 2009 & Ancient Iran bureaucracy and global imperial administrative system \\
Richard N. Frye & 1965 & Ancient heritage of Iran \\
Albert Tenek Almost & 1961 & History of Achaemenid Empire \\
& 2012 & Achaemenid history \\
Pierre Brayan & 2001 & Achaemenid Empire \\
& 1979 & Achaemenid \\
Mohammad A. Dondamayf & Political and economic history of the Achaemenid \\
Amli Court & 1999 & Ancient Iran \\
P.R.A. Mori & 1937 & Achaemenid inscriptions \\
Pierre Lochak & 2004 &
\end{tabular}

\section{Research Methodology}

According to the documents review and the qualitative data collection, the research methodology is "qualitative content analysis with directional approach ", which encompasses eight major steps: 1 . Choosing the subject of research; 2. Setting the Questions of the research; 3. Reviewing of legal resources; 4. Reviewing of historical resources; 5. identifying the dimension and components of rules and regulations system; 6. Collecting the data; 7. Coding the data; 8. Creating the categories; 9. reviewing and modifying the categories; 10 . Analysis of results and reporting. In terms of strategy, this research study is a case study because it studies "the laws and regulations of the Achaemenid Empire". In terms of orientation, it is a basic research because it explores and explains the features of Achaemenid Empire's laws and regulations. In terms of goals, it is an exploratory and descriptive research, because it seeks a scientific knowledge and describing the situation of laws and regulations of the Achaemenid Empire and its components, and it pays attention to the status and existing relations, common beliefs, current processes, evident works or growing trends (Khaki, 2005: 210). It is exploration because it has been done about a new subject [laws and regulation system in the Achaemenid Empire] that there is not sufficient information about it (Atslander, 1992: 78).

\section{Methods of Research Data Collection}

The necessary information in this research was collected by studying the documents and evidence, books, articles and other library materials. The statistical population in this study is defined as "all books, articles, reports, and available journals related to the Achaemenid Empire." Statistical samples in this research are divided into two categories, which include: the first group"foreign sources" includes articles, books, and researches and... foreign authors that are more in the form of original text translation and tablets and evidences and observations and the author's own knowledge and are less in the form of data recreation and rearranged and reestablishing. The second group "domestic resources" includes articles, books and researches and...local authors that are more in the form of authoring, translation, recreation, rearranged and reestablishing. In the meantime, there are also very valuable and precious resources.

The tools used to collect data in this study are "note" and taking notes and data coding have been used based on statistical population. 


\section{Research Findings}

After Darius established peace and security in the entire empire, he found out that the administration of a vast territory in diversity of races and cultures requires the collection of previous laws and legislation of new rules that meet the requirements and needs of that period do that he could able to manage the vast and incongruous emperor. For legislating new laws, he used sources such as previous tradition, Aryan's laws that had an ethnic aspect and good and honorable laws of other nations. Moreover, the king himself was also the source of new laws that fit the requirements and needs of that day. Darius ordered that all laws would be collected from all over the empire and then be developed. The laws were notified by the king, this was a kind of legitimacy and acceptance of the law; because the king was a representative of Ahura Mazda on earth and his will be an expression of the will of Ahura Mazda. A copy of the laws was kept in the archives of the centers and each Satrapi, also the heralds were crying the laws in all areas and satrapies and informing the people. Probably a copy of the laws was kept on the scrolls or stone inscriptions and were set up in the city's main squares and crowded and busy streets so that it could be in front of the public eye, just like the Hammurabi law was written on a plaque and was installed in the main square or the Egyptian laws were written on the columns of the Pharaoh's palace. For example, Darius ordered the satrap of Egypt to send the knowledgeable experts in law, including judges, teachers, soldiers, clerics and...to the center so that they develop the Egypt set of rules.

\section{Source of Law}

In the Achaemenid Empire, several sources were used for codification of the law as "the laws which were inherited from the Medians period, and they were consisted of Aryan and non-Aryan traditions " "the laws that were the executive from Persian point of view and had an ethnic aspect, " good and honorable laws of dominating territories "and" the king (the central government)."

"The laws that imposed by Darius and then with minor changes came into force until the end of the regime was divided into three categories: 1.the rules that were inherited during Medians times and derived from Aryan and non-Aryan tradition 2. The laws that had been taken from dominated lands, especially Ashur, Babylon, and Egypt 3 The laws that were executive in Persians and had an ethnic aspect "(Ghadiani, 2006: 165)." Two sets of rules that probably were a reflection of two sets of court and were for their administration, were applied in the states. A set was the same local laws that were come over based on customs, habits and local developments. Another set was Persian laws or empire regulations, which was sourced from imperial authority "(Wiesehöfer, 1998: 47). The laws that imposed by Darius and then with minor changes came into force until the end of the regime was divided into three categories: the rules that were inherited during Medians times and derived from Aryan and non-Aryan tradition. The laws that had been taken from dominated lands, especially Ashur, Babylon, and Egypt. The laws that were executed in Persians and had an ethnic aspect "(Bayani, 2002: 165)." During the first Darius period, the law legislation of puppet nations was seriously acted.Moreover, in ancient laws, especially in Hammurabi law, a research has been done; the rules that were in different states were collected and were changed in terms of imperial policy in each of them that was necessary. The Persians had an old law that was to become the basis of the kingdom rules; with reference to the will of Ahura Mazda, the king could impose new laws "(Dandamayf, 1979: 13).

\section{Collecting, Editing the First Draft and Legitimizing the Law}

The laws were gathered from all over the empire, then, a draft of the legislations was developed. The king notified the law, and this was the legitimacy and acceptance to the law. Apparently, during editing, the law was adapted to the religion (Zoroastrianism) and was amended if necessary (Darvishi Niya, 2014:67).

"Finally, after collecting, mixing and editing, an aspect of god was given to all of them, because it was notified by the king and he obeyed the Ahura's orders himself" (Ghadiani, 2005: 165). "Darius was set to extend his administration, which requires the collection of rules and previous traditions as well as innovation and the creation of new laws, to meet the requirements of time and place and could manage a wide and heterogeneous empire with a single organized force. He knew himself as Ahura Mazda and his chosen representative on earth that he had to govern with his command and help: "I became a king because of Ahura Mazda's will. Ahura gave the kingdom to me. "So his commands must be obeyed and must be regarded as a divine commandment "(Bayani, 2002: 116)."After collecting, mixing and editing, a God's aspect has given to all of them, because they were notified by the king and he obeyed Ahura's orders himself" (Bayani, 2002: 179). "Achaemenids, as the most important governments of ancient Iran, the continuity of their government (secondary legitimacy) derived from divine charisma and the king of Iran was seen as the representative of God on earth. Accordingly, the king appointed officials and staff also had such legitimacy. In fact, the kingdom was a source and law drafter and policies determinator, hence, there were an inextricably and mingling linked between monarchy and religion. Tensar, a great spiritual, says: "Religion and King both have been born from one abdomen. Double Seyedeh that will never be 
separated "(Noori, 2003: 312 and 313)." The government of each state was set the state's legal articles of association" (Fry, 1344: 254). "The law, in the Achaemenid period was documented and its material was used. These legislations have had a close relationship with the provisions of the Zoroastrian religion "(Ghadiani, 2005: 166).

\section{Registration, Archived, and Notification}

After the king notified the written laws, many copies were written. One copy was sent to the Persepolis and another copy was sent to Satrapi where they were recorded, archived and kept for reference to the source. Meanwhile, heralds were blared the laws in any area and Satrapi and in the street and market and the main square of town to inform the public and to be aware of the law. Probably a copy of the law was written on scrolls or stone inscription and was installed in the city's main squares and crowded and busy streets so that they were seen by everyone (Darvishi niya, 2014: 68). "The first Darius at his court had an organized and wide archive. In Ekbatan treasure dating back to the time of the Medes and perhaps before it, all kinds of king's commandments, political notes, military agreements and economic and business contracts, encouraging letters, and decrees and the military political authorities notifications have been archived over there '(Ghadiani, 2005: 191).

"The Darius' different command text was written for the mentioned cases and right circulation of works, on papyrus and clay tablets and were sent to various areas and Satrapi to run. In this way, Darius provided an ordered and organized country with coherent and strong administrative organization and effective rules so that it was the great Cyrus' legacy, and it was unique in the world in terms of the discipline in the management and the extension of territory, up to that time "(Bayani, 2002: 118)."About amounts of cash revenue that were received to the Treasury with tax collection and how to use and spend it, there were detailed and regular rules that violations of it was considered the a very serious crime. These ways in clay tablets and various surviving documents from this period is almost seen "(Bayani, 2002: 193). 'Orders and letters that were issued by the king will be signed by him and in cases that persians were seen the king's signature in affiliated states, they bowed and praised it. There were places that yearbooks and letters were recorded there. This meaning from Ctesian writing was undertaken explicitly, and he as it has gone, will call these places Dyftray play Lee Kai that in the modern Persian, it should be called "royal office" (Pirnia, 2002: 1423).

"In Susa, the kingdom's commands and orders were drafted and were sent to various parts of the country where the translators were there that were slowly translated into the language of that place" (several of the French Orientalists, 1967: 49). "Today with information we have received from clay tablets, we have no doubt that Persepolis was the center management court of Achaemenid Empire and records of all economic events were archived here" (Rajabi, 2002: 233). " Editing of these laws was ended in 495 BC and the mentioned laws were kept in Aramaic demoti handwriting "(Dandamayf, 1979: 14).'In the State palace, there were archives that the Royal commands were kept in them. Administrative flow and regional bureaucratic were imposed from these archives"(Kurt, 1999: 114). "The heralds brought the national legislation to the people" (Dandamayf, 1979: 11).

\section{Various Laws}

In the Achaemenid Empire, the law and practice it was very important. In that period, there were many laws that include the entire social, political, economic life and all classes and people groups. Three categories of laws can be noted. The first category was general principles and policies that were sourced from the command of Cyrus the Great and was forced until the end of Achaemenid Empire. The second category was national, unified rules that were performed in the entire Empire, and its orders were issued from the center. the economic and financial laws (eg tax laws that were about the amount of cash revenues that was collected by taxes into the treasury, there were very exact rules about the tax rate and how to use and spend them that any violation of them was a serious crime), military and security laws, politics and loyalty to the King laws, laws and administrative orders (like the way of doing things that were issued from the center) and so on, can be referred. These rules that were known as king (Date rules) were sourced from the king's power. The third category was local and regional laws that were rooted in local traditions and customs, etc. many rules that were there in all aspects of social life (property, inheritance, custody, etc.), salary (physicians' fees, etc.) and many local and regional laws to solve descendants, can be pointed out. The totalities of these rules were based on the two law categories above and they should not have been in conflict with them.

It should be noted that many laws had both general and global aspect and regional and detailed aspect. For example, assume that when the satrap, military commander or judge have violated in one of satraps, the king invited him to the center and according to the laws (Dateh) of the king, he was punished, such as the trial by a judge that had been bribed and Cambyses ordered to peel his skin, tanned it and put it in in the judgment seat and ordered the judge's son to sit on the judgment seat and always keep in mind that which position he is sitting. It 
can be imagined that an animal or a personal four-legged has been entered a personal property, and has eaten his products, in such cases, these issues were settled based on traditions, customs and laws of the area. With same argument, it can be looked at other laws.

It should be noted that each Satrapi law may be somewhat different from other Satrapies, but this difference is more related to the implementation of any rules and not all of them. For illustration, an example would be helpful. Suppose that you are driving on a highway with your car in the United States. The speed limit is 60 miles in the state, the next state is 80 miles, and the next state is 110 miles. With this example it should be said that in the Achaemenid Empire, the laws of some Satrapi have been different according to tradition, customs and specific traditions of that area with other satraps, but it had an overall unity and it wasn't in contradiction with the king's rules set (Dateh) and imperial principles and general policy (Darvishinia, 2015: 69 and 70). "The government policy was based on three principles: 1. Respect for the principles and standards of living for all people and nations 2. Having secure borders to protect the empire 3. Obeying justice and legitimacy. Xenophon said the Persians obeyed these Cyrus' rules and principles to the end of the government "(Ghadiani, 2006: 160).

"With what has been obtained from the clay tablets, written documents on the skin (parchment) and inscriptions, many rules can be considered that include all the social, political, economical life cases, and also include all classes and groups of people "(Ghadiani, 2006: 165). "They should be acted based on laws that were collected carefully and with all the details in a series of work. "A set of codified laws" was an advanced culture graph of Achaemenid on one hand and on the other hand was very provisions. Legal issues and ownership, inheritance, custody and so on laws were codified in the Achaemenid period and its materials have been used "(Ghadiani, 2006: 166)." One of the most important actions of Darius was the establishment of tax with broad organization and new national laws. About the cash revenues that were sent in to the Treasury with tax collection and their usage and spending, there were detailed and organized that violating from them was a major crime, and we can see it in Darius; justice "(Ghadiani, 2006: 208 and 209).

"Two sets of rules that probably were a reflection of two sets of courts and were for running them were enforced in the States. A set was local laws that were come over based on customs, habits and local developments. Another set was Persian laws or regulations of the Empire, which was sourced from imperial authority "(Wiesehöfer, 1999: 47)."Darius was set to extend his administration, which requires the collection of rules and previous traditions as well as innovation and the creation of new laws, to meet the requirements of time and place and could manage a wide and heterogeneous empire with a single organized force. He based his work on the three principles of "regulation, justice and security" and for their implementation; he created a centralized administrative organization and tried to provide security and justice throughout the territory, with direct supervision of the work, in particular the work of Satrapies "(Bayani, 2003: 116)."With what has been obtained from the clay tablets, written documents on the skin (parchment) and scrolls, it can be outlined several laws that include all the social, political, economical life, and also include all classes and groups of people.

Judges should act according to the rules that were collected in a set carefully and with all the details. "Compiled set of rules" was an advanced cultural graph of Achaemenid on the one hand and on the other hand was many law cases "(Bayani, 2003: 179 and 180)."One of the most important actions of Darius was the establishment of tax office with broad organization and new national laws. )."About amounts of cash revenues that were received into the Treasury with tax collection and how to use and spend it, there were detailed and regular rules that violations of them was considered a very serious crime. "(Bayani, 2002: 193)."About the physician's fee, we have received information because also in Iran like Babylon in Hammurabi time in the doctor's fees had been determined" (several of the French Orientalists, 1968: 96).

\section{Summary and Conclusions}

According to preliminary data research and the research methodology (main categories, sub-categories, and formulating, encryption and creating categories) input, process and output can be considered for the laws and regulation system in the table 2 description. 
Table 2. Input, process and outputs of the laws and regulations of the Achaemenid Empire (the researcher)

\begin{tabular}{c} 
Input \\
\begin{tabular}{c} 
The King (central government) \\
Experts and knowledgeable people in the law (administrative, financial, legal, priests, soldiers, teachers, \\
\hline good and honorable laws of dominating territories, especialy Ashur, Babylon (eg, Hammurabi), Egypt and ... \\
\hline Laws that were executed in the Persians and had the ethnic aspects \\
Process \\
Collecting and reviewing laws \\
Drafting of the law \\
the legitimacy and recognizing of the law \\
giving Ahura's side of the law and promulgated by the King \\
Recording and archiving \\
On clay tablets, skin (parchment), scrolls and ... \\
Notification \\
Herald were blazed the laws, laws translating into other languages and sending them to the land \\
Output
\end{tabular} \\
\hline
\end{tabular}

\section{Government policies and general principles}

Government policy was based on three principles: 1. Respect to the principles and standards of living for all people and affiliated nations 2. Having secure borders to protect the empire 3. Obeying justice and legitimacy

\section{Imperial Codified rules (Dateh) set}

Economic and financial laws (eg tax laws, the cash amount of revenues that was sent to the treasury with collecting taxes, tax rates and the application and spending it), the military and security laws, political laws and loyalty to the King, laws and administrative orders (like the way things were done that were exported from the center) and many other national laws that were executed according to the king's law (Dateh) throughout the empire.

\section{Laws and regulations of Satrapi / regional / local / national}

Many laws that were for all aspects of social life (property, inheritance, custody, etc.), salary (physicians' fee, etc.), judgement laws, many laws for all classes and groups of people and many local and regional legislations to solve all descendants can be referred.

Egyptian law at the time of Darius the Jerusalem law at the time of first Artaxerxes

The presented model or the pattern in Figure 1 can be proposed for the laws and regulation system of the Achaemenid Empire. 


\section{Input}

1. The King (central government); 2. The experts and knowledgeable people in law, 3. The laws that were inherited from the Median period, and were derived from Aryans and non-Aryans traditions of the past; 4 . The good and honorable laws of dominating lands; 5 .

The laws that were an executive in Persians and had an ethnic aspect.

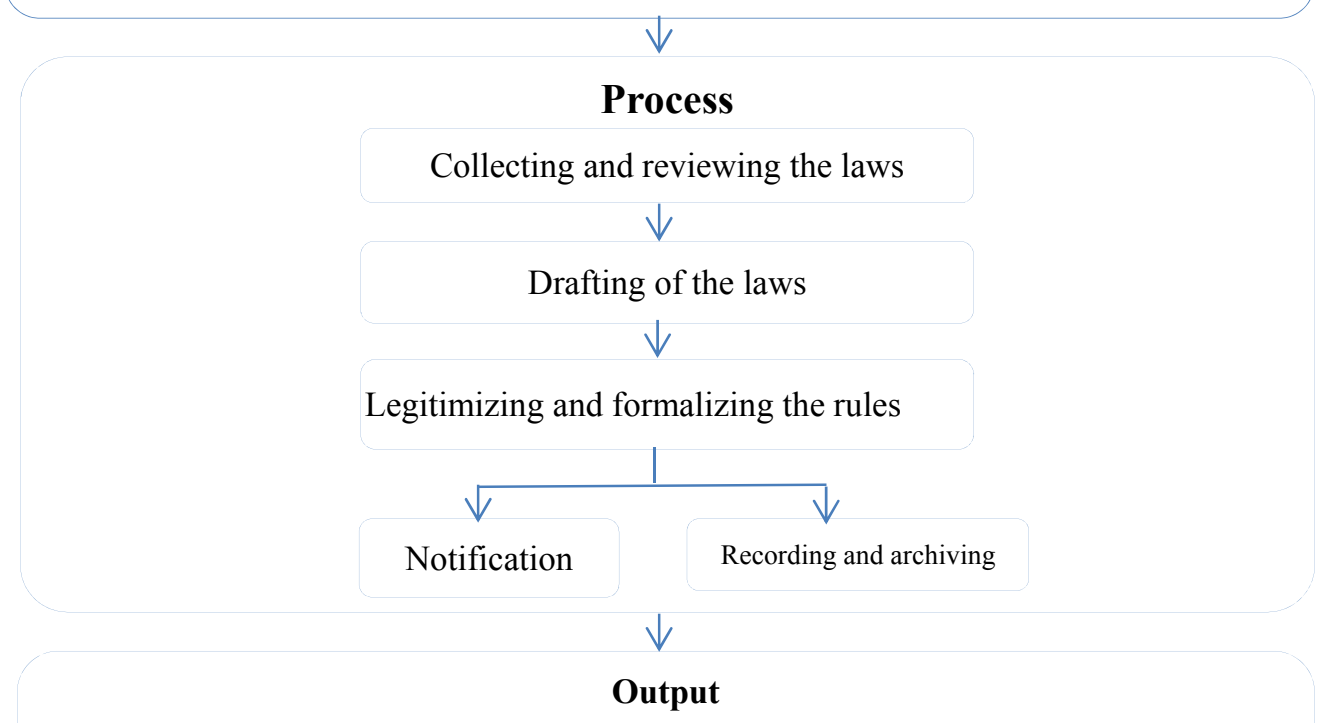

1. The principles and general policies of the government, 2. A set of codified empire rules

(Dateh); 3. Law and regulations of Satrapi / regional / local / national

Figure 1. The rules and regulation system of the Achaemenid Empire (the researcher)

\section{Findings for the Recent Laws and Regulations System}

Achaemenid compiled and analyzed all empire laws. For this work, they used all experts and knowledgeable people in the law. The law was given legitimacy and recognition. Set of codified laws were precisely and regularly archived so in cases of necessity they can be accessed. Laws were sent throughout the empire and were widely publicized. The following findings can be provided in this system:

- $\quad$ Using a set (group / team) of experts and knowledgeable people in the law;

- To gather and to review all existing laws;

- Using good and honorable laws of other countries;

- Localization of laws and matching them with Islam;

- Preparation and setting of codified laws in all fields;

- Broad publicity through the media (newspapers, radio and television, etc.) and sending new laws to relevant organizations;

- $\quad$ Laws must be accurate, clear, comprehensive and without the possibility of abusing.

- Flexibility and compatibility of the law with regard to local and regional differences;

- Taking into account all aspects of social, cultural, political and economical life in the legislation;

- Legislation related to religious minorities, according to their customs and general policies of the system;

- Law enforcement warranty and dealing decisively with offenders;

- Law enforcement for everyone, as the wives and relatives of the emperor also had to obey the rules. 


\section{References}

Atslander, P. (1993). The empirical research methods, Bijan Kazemzadeh, Mashhad, Razavi Cultural Affairs.

Bayani, S. (2003). Iran Ancient History (2), Mahmoud Jafari Dehghi, first.

Beygzadeh, S. (2009). Style of writing the rule, Third Edition, Tehran, Islamic parliament Research Center.

Dandamayf, Mohammed. A. (1980). Political and economic history of the Achaemenid, Mirkamal Nabipour.

Darvishi nia, M. M. (2014). Reviewing and explaining the features of Achaemenid Empire administration system, master's thesis, Tehran, Shahed University.

Frye, R. N. (1966). Iran ancint heritage, Masoud Rajab nia, translation and publishing firm.

Ghadiani, A. (2006). Iran history, culture and civilization in the period of Achaemenid, Tehran: publication of written culture.

Gorgi, A. (1989). Government in Islam. Tehran: Amir Kabir publishes.

Katouzian, N. (2008). the introduction of law and study in Iran legal system, printing 55, Tehran.

Khaki, G. (2006). The research methodology with an approach to the dissertation. Tehran: reflections.

Khalili, M. (1994). studying the Effect of changes in the constitution of the Islamic Republic of Iran after the Islamic Revolution, and how to review it, master's thesis in political science, faculty of law and political science at Tehran University.

Kurt, A. (2000). The Achaemenid, Morteza taqib far, Tehran: Phoenix.

Mesbah, M. T. (1994). Society and history from the perspective of the Quran, the Islamic Propagation Organization.

Noori, R. (2013). Foundations of public administration (theory of the government and general administration of Iran), first, Qom: Sobhan, Institute of Science.

Pirnia, H. (2003). Iran Ancient or detailed history of ancient Iran, vol. 2, Tehran, gallery book.

Rajabi, P. (2003). Missing Millennium, Bahman Hamidi, first published, Phoenix.

Several French Orientalists. (1968). Iranian civilization, Isa Behnam, enterprise translation and publishing.

Wiesehöfer, J. (1999). Ancient Iran, Morteza Taqib Far. Tehran: Phoenix.

\section{Copyrights}

Copyright for this article is retained by the author(s), with first publication rights granted to the journal.

This is an open-access article distributed under the terms and conditions of the Creative Commons Attribution license (http://creativecommons.org/licenses/by/3.0/). 